DOI: https://doi.org/10.47405/mjssh.v6i4.739

\begin{tabular}{|c|c|}
\hline Ting & Malaysian Journal of Social Sciences and Humanities (MJSSH) \\
\hline Malaysian Journal of & Volume 6, Issue 4, April 2021 \\
\hline (Mus-ssh) & e-ISSN : 2504-8562 \\
\hline & $\begin{array}{l}\text { Journal home page: } \\
\text { www.msocialsciences.com }\end{array}$ \\
\hline
\end{tabular}

\title{
TESL Teachers' Online Teaching during COVID-19: Preferences of Online Tools and Factors Affecting Behavioural Intention
}

\author{
Ting Ying Ying ${ }^{1}$, Azlina Abdul Aziz ${ }^{1}$ \\ ${ }_{1}^{1}$ Faculty of Education, Universiti Kebangsaan Malaysia (UKM) \\ Correspondence: Ting Ying Ying (amymelon@hotmail.com)
}

\begin{abstract}
The use of online tools has become more prominent as the global lockdown of education institutions in order to slow the spread of the novel coronavirus pandemic (COVID-19). Teachers all over the world resorted to continue the teaching and learning process online using different online tools. In this study, the preferred online tools, and the relationship between the factors of TESL teachers' use of online tools and their behavioural intention are investigated. A survey was conducted on 56 Malaysian TESL teachers using purposive sampling technique. The data were collected through online survey questionnaires assigned using Google Forms. The findings showed the top 3 major online tools used by TESL teachers were WhatsApp (80.4\%), Google Form (71.4\%), while Quizizz and YouTube both achieved a $62.5 \%$ among the 56 respondents. Regression analysis showed that Performance Expectancy, Effort Expectancy, Social Influence, and Facilitating Condition were positive predictors of teachers' Behavioural Intention to use online tools, with Effort Expectancy being the factor that affects Behavioural Intention the most. Since the findings pointed out that Effort Expectancy was the main factor that influences teachers' online teaching and learning experience, the ministry of education and online tools developers should ensure the online tools are user friendly to reduce teachers' burden and hence, encouraging the use of online tools.
\end{abstract}

Keywords: online tools, education, Teaching English as a Second Language (TESL), e-learning, Unified Theory of Acceptance and Use of Technology (UTAUT)

\section{Introduction}

Online tools have become increasingly important in education because of the rising need of teaching and learning to be done online, without face-to-face interactions. It is especially important in the current COVID-19 pandemic in which schools were closed and learning has since taken place online. According to data provided by UNESCO (2020), on 1st June 2020, these nationwide closures which involved 149 country-wide closures are impacting $68 \%$ of the world's student population, which is equivalent to $1,190,137,755$ students. In Malaysia, since 18th March 2020, the government has announced the Movement Control Order (MCO) or 'lockdown' which restricts people in the nation from mass movements and gatherings, travelling and closure of educational institutions, government and private premises (except those involved in essential services). Hence, Malaysian teachers have resorted to using the Internet and various online tools to get in touch with their students. The resort of using the Internet as a medium to get to students encouraged the use of online tools such as Google Classroom, Quizizz and many others. There were online tools designed specifically for education 
purposes such as Google Classroom and Quizizz; and there were online tools which served a wider purpose, such as WhatsApp that can be used for communication and socialising.

Past researches have shown that the proper use of ICT by the facilitators in their teaching do have positive effects and helps in students' learning success (Hennessy et al., 2005; McGorry, 2002). Hence, teachers play an important role in the effective use of ICT in education (Englund, Olofsson \& Price, 2017). Therefore, it is important to investigate the factors that influence teachers' adoption of ICT in their teaching so that measures could be taken out to maximise teachers' adoption of ICT in their teaching. Past researchers have developed models to explain factors of behavioral intention of the use of technology (Davis, Bagozzi \& Warshaw, 1989; Venkatesh, Morris, Davis \& Davis, 2003). In this study, the Unified Theory of Acceptance and Use of Technology (UTAUT) model was adopted to investigate the factors that influence TESL teachers' choice of online tools.

Past studies were conducted to investigate factors influencing teachers' use of technology in their teaching (Sadaf, Newby \& Ertmer, 2016; Schulz, Isabwe \& Reichert, 2015; McCulloch et al., 2018). However, these studies were carried out abroad, therefore, the factors influencing Malaysian teachers' use of technology in their teaching might differ. There were also studies that have been conducted to investigate factors influencing students' use of online tools or e-learning in foreign countries (Tan, 2013; Attuquayefio \& Addo, 2014; Gitau, 2016; Mahande \& Malago, 2019). However, these studies portrayed the factors of using online tools and e-learning from the students' perspective, which might be different from a teacher's perspective. In two studies conducted in the Malaysian context, Zakaria, Watson and Edwards (2010) and Thang et al. (2016) reported on the use of online tools by Malaysian students. Although these two studies were conducted in the Malaysian context, however, they were from the students' perspective, which might not portray the perspectives of teachers. Hence, studies are yet to be done to investigate the online tools that Malaysian teachers are currently using and the factors influencing teachers' behavioural intention to use the online tools. Therefore, this study bridges the gap by identifying the online tools used and factors of using them from the perspective of Malaysian teachers.

Malaysian teachers started to utilise Google Classroom, Google Meet and Zoom as a learning platform to assign study materials, notes and homework to their students during MCO (Soon \& Wong, 2020; Mokhtar, 2020). However, based on Raman and Rathakrishnan's (2018) study on the investigation of the use of an online learning platform, Frog VLE, Malaysian teachers responded that they were slightly reluctant in using Frog VLE in their teaching because it was not quite user friendly. Though this study merely presented the factors influencing the use of just one online tool, it intrigued the interest in finding out the factors of using online tools in general, especially during the COVID-19 period.

Ebrahimi and Jiar (2018) found out that the use of e learning is discouraging in Malaysia, in which $76 \%$ of public high schools in Malaysia use ICT for education whereas only $57 \%$ of teachers in Malaysian use ICT for education. Thang et al. (2016) reported Malaysian ESL undergraduates' perception on their ESL teachers' patterns of use of technological tools, which were only 'sometimes' to 'seldom' used by ESL teachers in four Malaysian universities. Currently, there were very few literatures on the factors of using online tools in language teaching and learning in the Malaysian school setting. Oliveira et. al. (2019) pointed out that due to the advancement of technological innovation in recent years, there is a dire need for more educational research that can foster better understanding on how learning can be supported by emerging technologies.

Furthermore, teachers' factors on the use of online tools could provide insights on the desired instructional design of the online tools which would eventually bring positive effects to the main stakeholder of online learning, i.e., the students. By identifying the factors that affect teachers' use of online tools, it could inform online tools developers to better understand the needs of teachers. Hence, the developers could modify their online tools so as to benefit the teachers as well as the learners. The findings could be useful to TESL teachers, learners, policy makers as well as online tools developers in terms of developing, adopting or adapting online tools in the teaching of English online. 
Hence, the study aims to identify the preferred online tools used by TESL teachers to teach English during the pandemic and to examine the relationship between the factors (i.e., Performance Expectancy, Effort Expectancy, Social Influence and Facilitating Conditions) and teachers' Behavioural Intention in using online tools. Thus, it is hoped that the findings would provide a better insight on the enhancement of the use of online tools in conducting online lessons. The Unified Theory of Acceptance and Use of Technology (UTAUT) model was adapted to understand the research objectives. Hence, this leads to the following research questions:

Research Question 1: What online tools do TESL teachers prefer to use during the COVID-19 pandemic?

Research Question 2: What is the relationship between the factors (performance expectancy, effort expectancy, social influence and facilitating conditions) and TESL teachers' behavioural intention to use online tools during COVID-19 pandemic?

Based on Research Question 2, the hypotheses of the study were developed.

Hypothesis 1: There is no relationship between Performance Expectancy and teachers' Behavioural Intention to use online tools

Hypothesis 2: There is no relationship between Effort Expectancy and teachers' Behavioural Intention to use online tools

Hypothesis 3: There is no relationship between Social Influence and teachers' Behavioural Intention to use online tools

Hypothesis 4: There is no relationship between Facilitating Condition and teachers' Behavioural Intention to use online tools

This article starts off with a simple introduction of the topic, followed by the literature review, methodology, findings, discussions and conclusions.

\section{Literature Review}

\section{E-learning}

The use of the Internet and online tools has opened a door of opportunities for teachers to approach their students in language teaching through the internet. According to Clark and Mayer (2016, p. 8), elearning is defined as 'instruction delivered on a digital device (such as a desktop computer, laptop computer, tablet, or smart phone) that is intended to support learning'. According to Clark and Mayer (2016), there are two types of e-learning: synchronous e-learning (virtual classrooms or webinars are used for real-time instructor-led training) and asynchronous e-learning (self-paced learning which allows individual learner to access learning at any time or any location).

\section{Online Tools for Language Teaching}

Several researchers have listed out and categorised a compilation of online tools which are suitable to be used in language learning (Godwin-Jones; 2009; Son, 2011; Walker, Davies \& Hewer; 2012). Table 1 shows the categorisation of online tools by the researchers.

Table 1: Categorisation of online tools

\begin{tabular}{ccc}
\hline Godwin-Jones; 2009 & Son, 2011 & $\begin{array}{c}\text { Walker, Davies \& } \\
\text { Hewer; 2012 }\end{array}$ \\
\hline- & Learning Management Systems/ & - \\
\hline
\end{tabular}



DOI: https://doi.org/10.47405/mjssh.v6i4.739

\begin{tabular}{|c|c|c|}
\hline Chat & $\begin{array}{c}\text { Communication } \\
\text { Live and Virtual World }\end{array}$ & $\begin{array}{c}- \\
\text { Chat rooms, MUDs, } \\
\text { MOOs and MUVEs } \\
\text { (virtual worlds) }\end{array}$ \\
\hline Social Bookmarking & $\begin{array}{l}\text { Social networking and } \\
\text { bookmarking }\end{array}$ & Social bookmarking \\
\hline Personal Publication Tools & Blogs and wikis & $\begin{array}{l}\text { Discussion lists, blogs, } \\
\text { wikis, social networking }\end{array}$ \\
\hline Writing Tool & Presentation & Image sharing, \\
\hline Media Player & Resource sharing & $\begin{array}{c}\text { Podcasting, Audio tools, } \\
\text { Video sharing, } \\
\text { Document sharing }\end{array}$ \\
\hline - & Website creation & - \\
\hline Quizzing/Polling & Website exercise creation & - \\
\hline- & Web search engines & - \\
\hline Language Tools & Dictionaries and concordancers & - \\
\hline $\begin{array}{l}\text { Calendar/To-do-list, } \quad \text { News } \\
\text { Feeds, File storage/distribution }\end{array}$ & Utilities & $\begin{array}{l}\text { Screen capture tools, } \\
\text { Animation tools, } \\
\text { Mashups }\end{array}$ \\
\hline
\end{tabular}

\section{Unified Theory of Acceptance and Use of Technology (UTAUT)}

UTAUT is a model derived by Venkatesh et al. (2003) to examine the intention of technology use (Behaviour Intention) and technology usage behaviour (Use Behaviour) based on four determinants (Performance Expectancy (PE), Effort Expectancy (EE), Social Influence (SI), Facilitating Conditions (FC), which are moderated by four moderators of key relationship (age, gender, experience and voluntariness of use to examine dynamic influences on the BI in using technologies. According to Fishbein and Ajzen (1976), BI refers to the probability that a person will perform certain behaviour. As cited in Lin, Lu and Liu (2013), Venkatesh et. al. (2003) proposed UTAUT which was integrated from eight models: Fishbein and Ajzen's Theory of Reasoned Action (TRA), Technology Acceptance Model (TAM), the Motivational Model (MM), Theory of Planned Behaviour (TPB), TAM and TPB combined, the model of PC utilisation (MPCU), the innovation diffusion theory (IDT) and the social cognitive theory (SCT). UTAUT is one of the most prevalent theoretical models for explaining the individual's behavioural intentions in the adoption of technologies (Lin, Lu \& Liu, 2013). Figure 1 epicts UTAUT's four core determinants and four moderators that influences users' behavioral intention as well as behaviour in using a technology.

Figure 1. Model of UTAUT

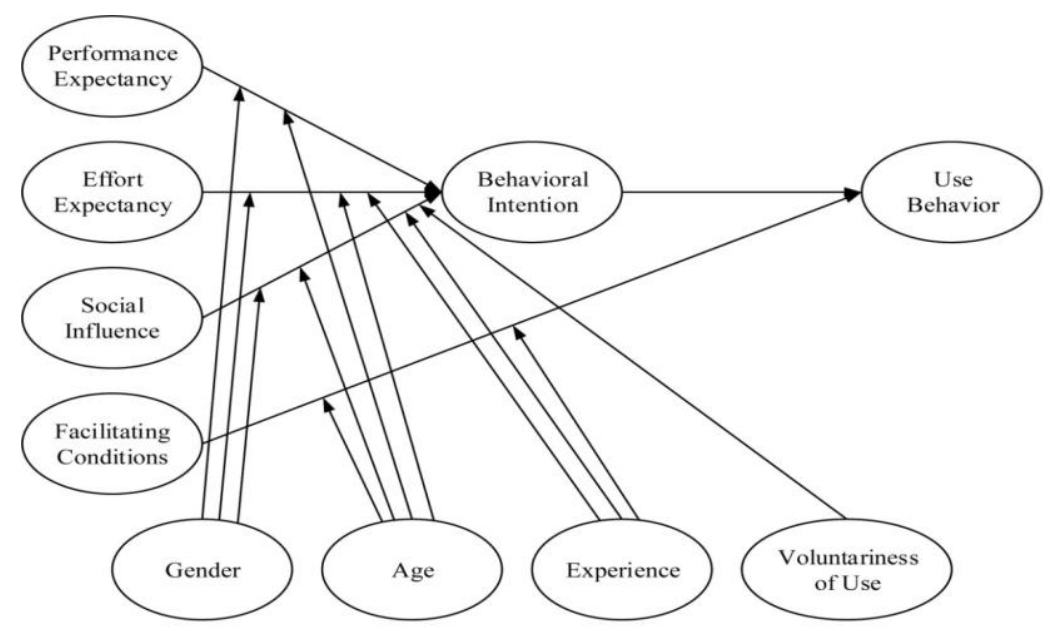

Source: Venkatesh, et al. (2003) 
DOI: https://doi.org/10.47405/mjssh.v6i4.739

The definitions of the four core determinants are tabulated in Table 2.

Table 2: Definitions of the core determinants in UTAUT

\begin{tabular}{|c|c|c|}
\hline & Core Determinant & Definition \\
\hline 1 & PE & $\begin{array}{l}\text { "The degree to which an individual believes that using the system } \\
\text { will help him or her attain gains in job performance" }\end{array}$ \\
\hline 2 & $\mathrm{EE}$ & "The degree of ease associated with the use of the system" \\
\hline 3 & SI & $\begin{array}{c}\text { "The degree to which an individual perceives that important others } \\
\text { believe he or she should use the new system" }\end{array}$ \\
\hline 4 & FC & $\begin{array}{l}\text { "The degree to which an individual believes that an organizational and } \\
\text { technical infrastructure exists to support use of the system" }\end{array}$ \\
\hline
\end{tabular}

Researchers have found different dominating factors of the use of technology in their studies. Some studies used difference terminologies to describe the factors, whereby perceived usefulness is similar to Performance Expectancy and perceived ease of use is similar to Effort Expectancy.

\section{Performance Expectancy}

Several studies identified Performance Expectancy as the main factor influencing the use of online tools (Gitau, 2016; Sangeeta \& Tandon, 2020; Pynoo et al., 2011). Teo et al. (2019) found out that perceived usefulness and enhances the adoption of Web 2.0 for teaching. This is similar to performance expectancy in which the teachers think that the tool is useful in enhancing their performance in teaching. Some other studies also found out that teachers' perception of the tool's usefulness influences their decision to use the tool (Aljaloud, Billingsley \& Kwan, 2019; Sadaf, Newby \& Ertmer, 2016).

\section{Effort Expectancy}

Nikou and Economides (2019) determined Perceived Ease of Use to be the most important determinant in teachers' intention to use mobile-based assessments. McCulloch et al. (2018) found out that teachers' technology integration decisions are made based on ease of use. On the contrary, Gitau (2016) reported that Effort Expectancy was perceived to be the least common factor influencing the use of Web 2.0 tools whereas and Sangeeta \& Tandon (2020) effort expectancy was reported to fail to drive teachers' adoption to online teaching.

\section{Social Influences}

Few studies also found out that social influence have a significant relationship with behavioural intention (Pynoo et al., 2011; Sangeeta \& Tandon, 2020).

\section{Facilitating Conditions}

Some studies highlighted Facilitating Conditions as factors that affect the use of technology (Tseng et al., 2019; Mei et al., 2018; Wong, 2016; Sangeeta \& Tandon, 2020; Huang, Teo \& Zhou, 2017; Teo et al., 2019; Prasojo et al., 2020, Wong, 2016; Mtebe, Mbwilo \& Kissaka, 2016; McCulloch et al., 2018). Yew and Tan (2020) found out that the most important factor that affected teachers' intention to adopt online educational technologies was the accessibility of infrastructure and learning resources. This is similar to the Facilitating Conditions in this study in which it was the physical conditions that affect teachers' intention. Tiba, Condy and Tunjera (2016) also reported that the benefits of technology for teaching and learning, and availability and accessibility of technology in schools were factors affecting teachers' use of technology.

\section{Conceptual Framework of the Study}


The UTAUT model by Venkatesh et. al. (2003) is the model underpinning this study. Venkatesh et. al. (2003) proposed three factors of Behavioural Intentions (BI) in UTAUT: Performance Expectancy (PE), Effort Expectancy (EE) and Social Influence (SI). Facilitating Conditions (FC) is the factor of Use Behaviour. However, since the study focuses on examining the factors affecting teachers' Behavioural Intention on the use of online tools, the four moderators of key relationship (age, gender, experience and voluntariness of use) were omitted in the study and Facilitating Conditions (FC) was considered as a factor that affects teachers' Behavioural Intention. Hence, questionnaires were developed to determine whether there is a relationship between these four core determinants (PE, EE, SI and FC) and teachers' Behavioural Intention in using the online tools.

Figure 2: Conceptual framework adapted from Venkatesh et. al. (2003)

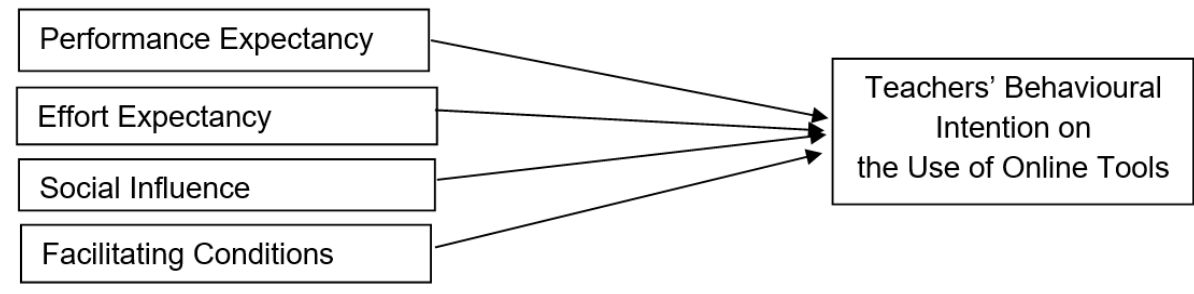

\section{Methodology}

\section{Research Design}

The study adopted a quantitative approach using the survey research design. The researcher chose to use a quantitative method design due to the nature of the research questions in which a survey questionnaire was assigned to collect data on the factors that influence TESL teachers' use of online teaching and learning tools based on the UTAUT model. Based on the literature review, previous studies on UTAUT theory mostly utilised surveys in their research (e.g., Venkatesh et al., 2003; Anderson \& Schwager, 2004; Moran, 2006; Wang \& Shih, 2009; Tan, 2013). Hence, based on the previous research, a non-experimental study was conducted, utilising a single survey instrument to find out about the samples' demographics, preferred online tools used, relationship between these four core determinants (PE, EE, SI and FC) and teachers' Behavioural Intention in using the online tools.

\section{Sampling}

The study was conducted on a sample of 56 TESL teachers who are taking a two-year part-time TESL master's course in Universiti Kebangsaan Malaysia. The non-probability sampling technique, which is purposive sampling was adopted. TESL teachers who teach English online during the pandemic were chosen for the purpose of this study. The procedure of sampling was by sending the survey link to the part-time TESL master's students' class WhatsApp groups. Those who clicked into the survey link and their responses would automatically become samples of the study. Purposive sampling was chosen because it helps to identify and select information-rich cases to make full and effective use of the limited resources (Patton, 2002). Therefore, in this study, individuals that have experience and knowledge about an area of interest are identified and selected (Creswell \& Clark, 2011).

The reason the part-time TESL master's students were chosen as the samples of this study is that the probability of getting samples that fit into the sampling requirement is higher. Since they were taking the TESL master's course, there was a higher percentage that these teachers fit in the criteria of the study's sample: TESL teachers who teach English using online teaching and learning tools during the MCO period. Hence, this could reduce invalid samples who do not fit in the context of the study.

Out of the 56 survey questionnaires collected, no respondent submitted incomplete questionnaires so none of the responses were removed. In addition, all the respondents who responded $(n=56)$ were valid since all samples were purposively sampled and fulfilled the criteria of 'teaching English online' and 
'uses online teaching and learning tools every week'. Hence, the total data being analysed was 56 . As shown in Table 3, all teachers used online tools every week though differing in the frequency of use.

Table 3: Online Tools Use Behaviour of the Samples

\begin{tabular}{lcc}
\hline & Number of participants & Percentage (\%) \\
\hline $\begin{array}{l}\text { Use Behaviour (Hours spent on online teaching } \\
\text { and learning tools per week during the MCO }\end{array}$ & & \\
period) & & \\
$0-1$ hour & 11 & 19.6 \\
1-2 hours & 16 & 28.6 \\
2-3 hours & 10 & 17.9 \\
3-4 hours & 4 & 7.1 \\
4-5 hours & 6 & 10.7 \\
5-6 hours & 5 & 8.9 \\
6 hours and above & 4 & 7.1 \\
\hline
\end{tabular}

\section{Research Instrument}

The current study utilised a multi-sections survey questionnaire to gather data on TESL teachers' demographics, online teaching and learning tools used and their perceptions of using online teaching and learning tools. The survey questionnaire was created using Google Forms, an online survey form. The answers to the questions were presented using the Likert scale format, and checkboxes.

This instrument consists of eight parts. Section A consists of the demographic information from participants, such as gender, age, years of teaching experience, type of school they are teaching in, the state they are teaching in, the location of their school, whether or not they conduct online teaching and hours spent on online teaching. Section B included only one item, which is directed to identify the teachers' preferred online teaching and learning tools. Sections C, D, E and F of the questionnaire are items adapted based on the constructs in the UTAUT model by Venkatesh et al. (2003) to identify the teachers' Performance Expectancy, Effort Expectancy, Social Influence and Facilitating Conditions respectively. Section $\mathrm{G}$ was directed to identify teachers' Behavioural Intention on the use of online tools. The items are measured with a Likert-type 5-point scale: $1=$ strongly disagree, $2=$ disagree, $3=$ neutral, $4=$ agree and $5=$ strongly agree. There were four items each in Sections C, D, F and G, whereas Section E consisted of five items.

The scales created by Venkatesh et al. (2003) were initially used to measure the behavioural intent of using a technology and the scales in were validated and was able to account for 70 percent of the variance in technology usage intention.

\section{Data Collection Procedures}

All data was collected through the Internet. The survey questionnaire was created using Google Forms and distributed through WhatsApp groups of with TESL teachers in it. This is due to the fact that the TESL teachers who were in the WhatsApp group were all over Malaysia and distance poses a barrier for face-to-face data collection to take place. In addition, during the period of proposing the study, Malaysia was still within the MCO period and close contacts with people were not advisable.

Furthermore, the use of the online survey tool, Google Forms, allowed the researcher to keep the data in digital form, which could prevent data loss or damage compared to paper surveys. The data collected could also easily be accessed and imported with Excel, saving the researcher's tremendous amount of time.

The teachers who voluntarily participate in this anonymous survey would enter the survey through the link provided. From the link, they would be informed about the purpose of the study, estimated time 
required for the survey and that the results of the survey would be solely used for scholarly purposes only.

In order to avoid incomplete responses, the function 'required' was activated for every question in the survey. Once this function is activated, the respondents would be inhibited from proceeding to a next section unless they had completed all the questions in a section.

The survey link was opened for responses for one month. The results of the survey were provided by Google Forms, which were imported into Excel for data analysis.

\section{Data Analysis Procedure}

After the time for collecting survey responses was up, the researcher deactivated the accepting responses' function of the survey in Google Forms. Data collected from the survey was imported into Excel and then into the Statistical Package for the Social Sciences (SPSS) system (Version 25.0). SPSS was used to analyse the data using descriptive statistics, reliability analysis, correlation analysis and regression analysis.

The demographics of the participants, which were considered categorical variables were calculated using frequency counts and percentages. Section B of the survey which gathered data on teachers' preferred online teaching and learning tools were analysed using frequency counts and percentages which were presented in the form of a table to see the preferred online teaching and learning tools used by TESL teachers.

Sections C, D, E, F and G which comprised the UTAUT constructs were analysed using descriptive statistics, correlation analysis and simple linear regression.

\section{Reliability analysis}

Cronbach's alpha reliability coefficient was calculated for the five constructs (PE, EE, SI, FC and BI) to measure the internal consistency of the scales in the same construct. A coefficient of .93 is considered a high coefficient, .6 is considered an acceptable level for determining whether the scale has internal consistency whereas .72 is considered having a satisfactory level of internal consistency (Creswell, 2012). The study adopts a confidence interval of 95 percent because for social sciences research, a 95 percent confidence interval was desired in order to achieve conclusion validity (Trochim, 2006).

Table 4: Cronbach's Alpha values of the constructs

\begin{tabular}{lcc}
\hline Factors & Number of items & Cronbach's Alpha \\
\hline Performance Expectancy & 4 & .871 \\
Effort Expectancy & 4 & .929 \\
Social Influence & 5 & .874 \\
Facilitating Conditions & 4 & .761 \\
Behavioural Intention & 4 & .683 \\
\hline
\end{tabular}

As shown in Table 4, all of the constructs except Behavioural Intention have a Cronbach' Alpha coefficient of more than 0.7. According to various reports, the acceptable values of alpha ranges from 0.70 to 0.95 (Bland \& Altman, 1997; DeVellis, 2016). Whereas for the Behavioural Intention construct which only achieved 0.683 of the Cronbach's Alpha coefficient is still acceptable since the number of items is very small, which was only four items. 


\section{Findings}

The purposes of the study were to (i) determine online tools that teachers prefer to use, and (ii) determine the relationship between the factors that influence teachers' use of online tools and their behaviour intention of using the online tools.

\section{Research Question 1: What online tools do TESL teachers prefer to use during the COVID-19 pandemic?}

Figure 3: Preferred online teaching and learning tools by teachers while conducting teaching and learning activities during the COVID-19 pandemic

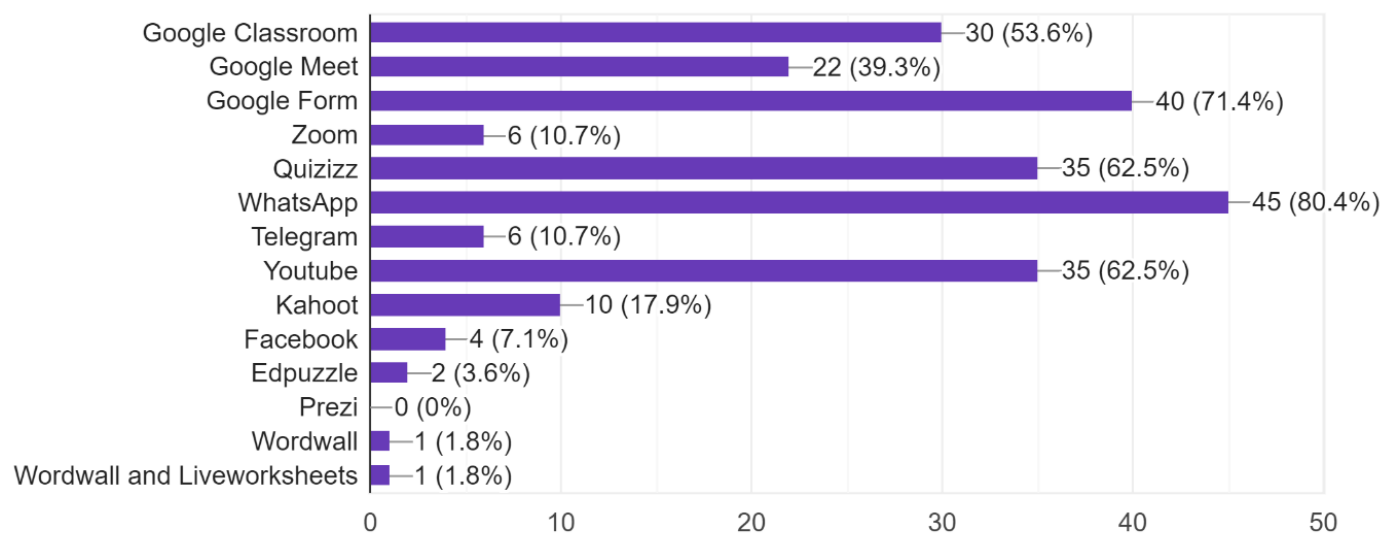

In the survey questionnaire, the respondents were asked to choose up to five most preferred online teaching and learning tools while they were conducting their teaching and learning activities during the MCO period. Out of the 56 respondents, there were some of the respondents reported less than five online tools. Based on Figure 3, the most preferred online tool was WhatsApp, chosen by 45 respondents, equivalent to $80.4 \%$ of the total respondents $(n=56)$. The second preferred online tool was Google Form, chosen by 40 respondents, equivalent to $71.4 \%$ of the total respondents. On the third place were two online tools, Quizizz and YouTube, in which 35 respondents $(62.5 \%$ of the total respondents) chose both of these tools. Following closely behind were Google Classroom (53.6\%) and Google Meet (39.3\%). None of the respondents used Prezi in their online teaching and learning.

\section{Research Question 2: What is the relationship between the factors (Performance Expectancy, Effort Expectancy, Social Influence and Facilitating Conditions) and TESL teachers' Behavioural Intention to use online tools during COVID-19 pandemic?}

\section{Descriptive analysis for the variables}

Prior to determining the relationship between the factors (Performance Expectancy, Effort Expectancy, Social Influence and Facilitating Conditions) and TESL teachers' Behavioural Intention to use online tools during COVID-19 pandemic, descriptive analysis was conducted to present the data of each of the constructs. The data for each construct was tabulated in Table 5.

Table 5. Descriptive analysis for the constructs in the UTAUT model

\begin{tabular}{lll}
\hline Constructs of the use of online tools in teaching English & M & SD \\
\hline Performance Expectancy (PE) & 3.8661 & .72608 \\
Effort Expectancy (EF) & 3.9018 & .77412 \\
Social Influence (SI) & 3.8036 & .78485 \\
Facilitating Conditions (FC) & 4.1071 & .64289 \\
Behavioural Intention (BI) & 4.2634 & .41126 \\
\hline
\end{tabular}


From Table 5, the respondents showed high Behavioural Intention (BI) to use online tools in teaching English (mean=4.26) out of a 5-point Likert scale. This implies that the teachers mostly have high behavioural intention to use online teaching and learning tools.

In terms of the factors, all factors reported a mean higher than 3, implying that teachers generally agree that the factors affected their behavioural intention of using online tools. Out of the four factors, FC reported the highest mean out of the four factors, which is 4.10 . This implies that teachers generally think that having the necessary physical resources, knowledge and skills of an online tool influences their behavioural intention of using online tools.

Lining up after FC are EF (mean=3.90), PE (mean=3.86) and SI (mean=3.80). Teachers perceived that how easy an online tool can be used is quite important whereas with SI at the mean of 3.80 implies that teachers think that the people around them do not influence their choice to use online tools as much as other factors.

\section{Correlation analysis for the variables}

Hair, Anderson, Tatham and Black (1998) suggested that the Pearson correlation factor loadings to be greater than 0.50. Table 6 shows the correlation data analysis. In the study, all the factor results of items in this study are higher than 0.5, except the correlation between EE and SI factors (0.484). All variables in the test are significant $(\mathrm{p}<.01)$. Hence, all the variables in the study have adequate reliability and convergent validity. If the Pearson's Correlation coefficient is from +.40 to +.69 , it means the variables have strong positive relationship. The strongest correlation out of all the independent variables with the dependent variable (BI) is EE, with a Pearson's correlation coefficient of .647, $r(54)=p<.01$. The weakest correlation out of all the independent variables with the dependent variable (BI) is SI, with a Pearson correlation value of .524, $\mathrm{r}(54)=\mathrm{p}<.01$. This implies that the relationship between the variables $\mathrm{EE}$ and $\mathrm{BI}$ is stronger as compared to the relationship between the variable SI and BI.

Table 6: Correlation of Factors

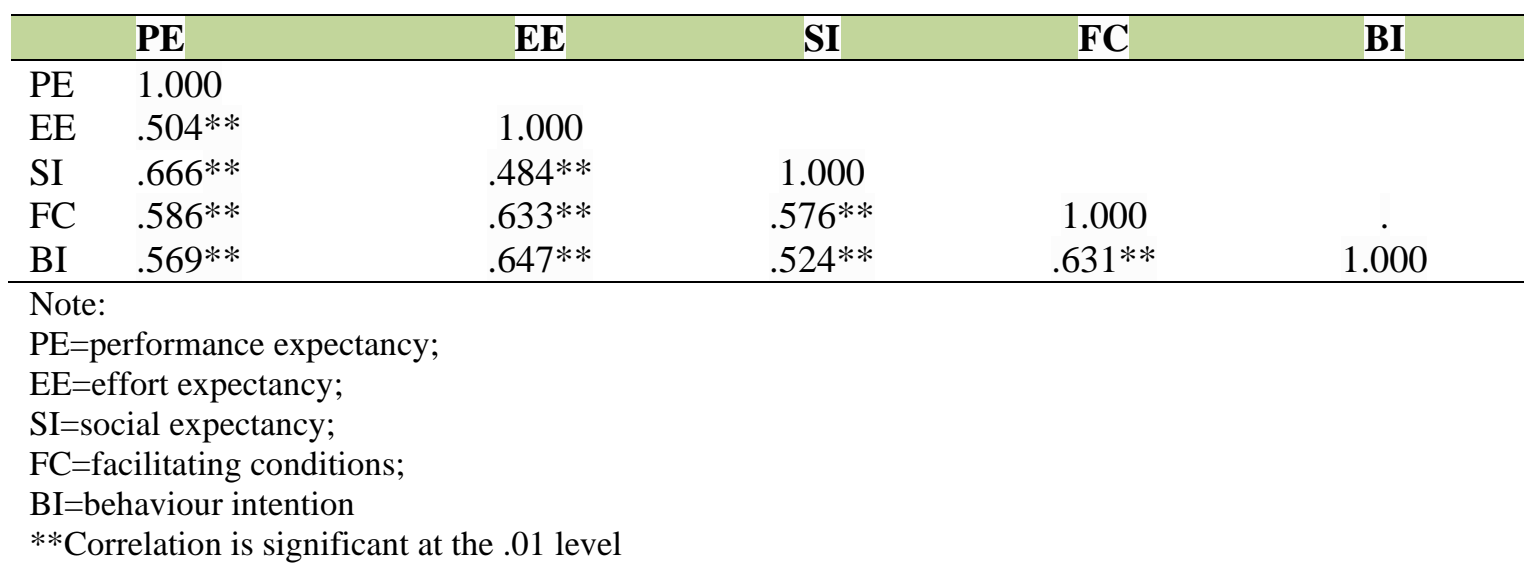

\section{Regression analysis for the variables}

Simple linear regression analysis was conducted to investigate the relationship between PE, EE, SI and FC on the teachers' BI. As shown in Table 7, all of the independent variables are significant in predicting the dependent variable $(\mathrm{BI})$. The variable with the highest $\mathrm{R} 2$, EE $(\mathrm{R} 2=.418)$ indicated that approximately $41.8 \%$ of the variation in teachers' BI can be explained by EE. 
DOI: https://doi.org/10.47405/mjssh.v6i4.739

Table 7. Regression of Factors on Intention to Use (BI)

\begin{tabular}{llcc}
\hline & Regression Coefficient, B & t-value & $\mathbf{R}^{2}$ \\
\hline PE & .322 & $5.089 * * *$ & .324 \\
EE & .344 & $6.230^{* * *}$ & .418 \\
SI & .274 & $4.518^{* * *}$ & .274 \\
FC & .403 & $5.970^{* * *}$ & .398 \\
\hline
\end{tabular}

Note. PE=performance expectancy; EE=effort expectancy; SI=social expectancy; FC=facilitating conditions; BI=behaviour intention

$* * * \mathrm{p}<.001$

\section{Confirmation of Hypotheses}

Hence, based on the results, all the null hypotheses are rejected.

The results showed that teachers' Performance Expectancy positively affects their Behavioural Intention to use online tools $(\mathrm{B}=.322, \mathrm{p}<0.001)$. This means that when teachers expect an online tool could increase their performance, they increase their intentions to use it.

The teachers' Effect Expectancy also positively affects their Behavioural Intention to use online tools ( $\mathrm{B}=.344, \mathrm{p}<0.001)$. This means that when teachers expect an online tool is easy to use, they increase their intentions to use it.

Furthermore, teachers' Social Influence also positively affects their Behavioural Intention to use online tools $(\mathrm{B}=.274, \mathrm{p}<0.001)$. This means that when the people around the teachers expect suggest them to use an online tool, they increase their intentions to use it.

Lastly, teachers' Facilitating Conditions also positively affects their Behavioural Intention to use online tools $(\mathrm{B}=.403, \mathrm{p}<0.001)$. This means that when teachers have favourable facilitating conditions to use the online tools, they increase their intentions to use it.

\section{Discussion}

This study aimed to gather data on the online tools used by teaching during COVID-19 and the relationship between the factors (Performance Expectancy, Effort Expectancy, Social Influence and Facilitating Conditions) and TESL teachers' Behavioural Intention to use online tools during COVID19 pandemic.

\section{Preferred online tools}

Based on the findings, the most preferred tool was WhatsApp. This finding could be possibly explained using Gon and Rawekar's (2017) study which reported that WhatsApp surpasses didactic lectures in terms of the constant availability of the facilitator and learning anytime anywhere is possible with the use of WhatsApp. In addition, Bouhnik, Deshen and Gan (2014) found out that teachers use class WhatsApp groups to (i) communicate with students, (ii) nurturing the social atmosphere, (iii) creating dialogue and encouraging sharing among students; and (iv) as a learning platform. The teachers in the study also mentioned the technical advantages of WhatsApp (easy to operate, low cost), educational advantages (creating a pleasant environment and in-depth acquaintance with their students); and instructional advantages (accessibility to materials, teacher availability) (Bouhnik, Deshen \& Gan, 2014).

This finding is coherent with the wider Malaysian context. According to a survey conducted by Telenor Group, a vast majority of Malaysians (62\%) ranked messaging apps, mainly WhatsApp, as the most important communication tool and $80 \%$ of Malaysians use messaging apps every day (Telenor Group, 2016). Since it is a very common tool to Malaysians, teachers, less parents would face technical issues 
in gaining access to learning materials as compared newly-introduced online tools such as Google Classroom, Google Meet and Quizizz.

On the second place was Google Form (71.4\%). This is in line with recent studies, in which Google Forms has started to be used for assessment in education (Kurniawati \& Lestari, 2020; Marqués-Sulé et al., 2017; Douell, 2020). This might due to the fact that WhatsApp was inconvenient in assessing the students and getting back their results of assessment. Hence, Google Form was utilised by teachers to assign quizzes to assess their students after they had given out the learning material via WhatsApp or any other online tools.

Following closely was another online quiz, Quizizz (62.5\%). This is in line with recent studies, in which Quizizz were used for assessment in education (Zuhriyah \& Pratolo, 2020; Rahayu \& Purnawarman, 2019; Darmawan, Daeni \& Listiaji, 2020; Junior, 2020; Amalia, 2020). YouTube $(62.5 \%)$ was also equally preferred because teachers could assign YouTube videos as learning materials that can be assessed any time as long as the students were given the links. This is in line with Moghavvemi et al.'s (2018) study which revealed that university students use YouTube for entertainment, information seeking and academic learning, hence, implying that instructors should integrate YouTube resources into their course materials and activities.

Following closely behind Quizizz and YouTube were Google Classroom (53.6\%) and Google Meet (39.3\%). Following the school closures due to the pandemic, it was reported that there were over 100 million active users of Google Classroom (De Vynck \& Bergen, 2020). Though not at the first place, Google Classroom has achieved a 53.6\% as a preferred tool by Malaysian TESL teachers. Google Meet has been widely used for online teaching during COVID-19 (Al-Maroof et al., 2020; Verma et al., 2020; Iivari, Sharma \& Ventä-Olkkonen, 2020). However, in the current study, one of the teacher teaching in the rural area responded that she did not use Google Meet due to the unstable internet connection at her area.

All in all, looking at the top three preferred online tools, it is clearly shown that teachers use a mixture of online tools which serves different purposes in order to get their teaching carried out, in which WhatsApp could be used for communication purpose, Google Form and Quizizz used for assessment purpose, and YouTube used for learning presentation purpose.

\section{Factors affecting the Behavioural Intention of using online tools}

The summary of the findings is shown in Figure 4, in which there are correlations between all the variables and all the independent variables are good predictor variables of the outcome variable (BI).

Figure 4. The result of the UTAUT model in this study

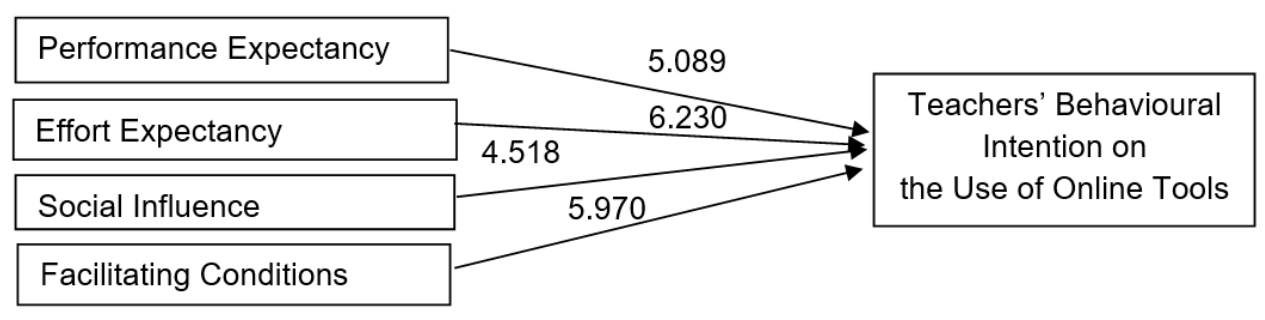

The findings support the UTAUT's model's use to study the factors of using online tools among TESL teachers in which all the four main determinants of the UTAUT model, PE, EE, SI and FC are contributing factors to the Behavioural Intention of using a technology.

Based on the correlation analysis, EE was found to have the strongest correlation with BI out of all the four factors proposed in the UTAUT model, $r=0.647$. The correlation analysis was at variance with the regression analysis, in which EE also constitutes the highest R2 among all the four factors. The higher the R2 is, it implies that the more percentage of the variation in teachers' BI can be explained by 
the independent variable. EE reported the highest $\mathrm{R}$ square, $(\mathrm{R} 2=.418)$, indicating that approximately $41.8 \%$ of the variation in teachers' BI can be explained by EE. This implies that teachers are more inclined to use an online tool if the online tool is easy to use and they have the necessary skills to use it. This finding corresponds with Raman and Rathakrishnan's (2018) study on e-learning in the Malaysian context in which teachers are reluctant to use (BI) Frog VLE because it was not user friendly (low EE).

These findings also corroborate the results reported in previous research, confirming that EE is a significant predictor of the use of online tools (Nikou \& Economides, 2019; McCulloch et al., 2018).

However, this finding was contradictory to Gitau's (2016) study in which EE was perceived to be the least common factor which influences the use of Web 2.0 tools because the respondents think that some of the tools were not easy to use. However, Gitau's (2016) study was conducted in the Kenyan Public Universities context, on both the teachers and students, hence, possibly resulting in the difference in the findings with the current study. This finding also contradicts with Sangeeta \& Tandon's (2020) study conducted in Indian schools, which revealed that EE failed to drive teachers' adoption to online teaching. However, most of the samples in Sangeeta \& Tandon's (2020) study were senior teachers and Venkatesh et al. (2003) pointed out that the impact of effort expectancy dilutes with experience. Whereas, in this study, most of the teachers have 10 years teaching experience, which is not considered as senior teachers, and therefore, differs from the context in Sangeeta \& Tandon's (2020) study.

\section{Implications}

The findings of this study provide significant implications to the Malaysian TESL teachers, online tools designers and the Ministry of Education (MOE). First of all, this study provides enlightenment on the current usage of online tools to teach English in the Malaysian context. Hence, teachers will get to know more about online tools that are easy to use and suitable for teaching English and how to combine the usage of online tools for different purposes.

Secondly, since EE is perceived as the most important factor that influences teachers' use of online tools, online tools designers should improve their online tools to make their user interfaces easier to operate. The Ministry of Education (MOE) should also conduct surveys on how to improve the online tools to reduce teachers' workload while using the tools. Hence, collaborations could be made between MOE and online tools developers to further enhance the user-friendliness of the online tools.

Thirdly, since FC is the second most important factor that determines teachers' behavioural intention of using the online tools, the government should make improvements on the internet connectivity throughout the country, so that teachers and pupils from all parts of the country have access to stable internet connection. Teacher do not have to compromise to the poor internet connection by using online tools that consume less internet.

\section{Conclusion}

The two findings of the study are (i) WhatsApp was the most preferred online tool; and (ii) all the four factors influence Malaysian TESL teachers' use of online tools, with Effort Expectancy as the most contributing factor to teachers' behavioural intention of using online tools.

The teachers in this study regard how easy the online tool can be used as the most important factor in their behavioural intention of using the online tool. This could be related to the prevailing issue of heavy workload among Malaysian teachers, as acknowledged by Cheok and Wong (2016) and Shanmugam and Lee (2017). Cheok and Wong (2016) conducted a case study on 12 teachers and reported that the teachers' heavy workload interferes with their predetermination of using Frog VLE, a virtual learning environment that MOE has adopted. Shanmugam and Lee (2017) also reported that one of the challenges that Malaysian teachers face while conducting action research is because of time 
constrain, in which teachers have heavy workload in teaching and clerical work. Referring to the heavy workload of Malaysian teachers, it is possible that the heavy workload has driven teachers to turn to effort-saving online tools in order to reduce their workload. In light of this, online tools should be designed in a way that is effort-saving for teachers, so that teachers could fully utilise the online tools in their online teaching.

\section{Limitations of the Study and Recommendations}

However, there are several limitations present in the current study. First of all, although the samples are chosen through purposive sampling, and that the samples chosen were based on the criteria 'TESL teachers who teach English using online teaching and learning tools during the MCO period', however, the samples' demographic information are very widely spread. For example, demographic details such as gender, teaching experience and teaching area. Therefore, the unequal dispersion of the demographic data of the samples might not be able to represent the whole situation in the Malaysian ESL context. Furthermore, the sample size for the current study is quite small, which is 56 TESL teachers. Therefore, there might be issues in terms of external validity, whether or not the results can be generalised to the population.

Another methodological limitation is that the current study collects data using cross-sectional methods, in which the data are collected at one point of time on different samples. Therefore, the teachers' behaviours on the use of online tools are not collected over a period of time and hence, it does not provide data over a period of time.

Therefore, further studies are suggested to be conducted on a larger number of samples, with equal distribution of samples from different demographic backgrounds so that the findings could be generalised to the wider Malaysian context. Other than that, researchers can also be done to validate the UTAUT model in other education contexts in different countries.

In conclusion, teachers are one of the key factors to ensure success in e-learning, therefore, the findings of studies that study the factors that affect teachers' use of online tools should be thoroughly made use to increase the behaviour intention of using the online tools among teachers.

\section{References}

Aljaloud, A., Billingsley, W., \& Kwan, P. (2019). Factors that influence teachers' decisions to use smartphone clicker apps to enhance teacher-student interactions in university classrooms in Saudi Arabia. Learning: Research and Practice, 5(1), 67-86.

Al-Maroof, R. S., Salloum, S. A., Hassanien, A. E., \& Shaalan, K. (2020). Fear from COVID-19 and technology adoption: the impact of Google Meet during Coronavirus pandemic. Interactive Learning Environments, 1-16.

Amalia, D. F. (2020). Quizizz Website as an Online Assessment for English Teaching and Learning: Students' Perspectives. Jo-ELT (Journal of English Language Teaching) Fakultas Pendidikan Bahasa \& Seni Prodi Pendidikan Bahasa Inggris IKIP, 7(1), 1-8.

Anderson, J. E., \& Schwager, P. H. (2004, February). SME adoption of wireless LAN technology: applying the UTAUT model. In Proceedings of the 7th annual conference of the southern association for information systems (Vol. 7, pp. 39-43).

Attuquayefio, S., \& Addo, H. (2014). Using the UTAUT model to analyze students' ICT adoption. International Journal of Education and Development using ICT, 10(3).

Bland, J. M., \& Altman, D. G. (1997). Statistics notes: Cronbach's alpha. Bmj, 314(7080), 572.

Bouhnik, D., Deshen, M., \& Gan, R. (2014). WhatsApp goes to school: Mobile instant messaging between teachers and students. Journal of Information Technology Education: Research, 13(1), 217-231.

Cheok, M. L., \& Wong, S. L. (2016). Frog virtual learning environment for Malaysian schools: Exploring teachers' experience. In ICT in education in global context (pp. 201-209). Springer, Singapore. 
Clark, R. C., \& Mayer, R. E. (2016). E-learning and the science of instruction: Proven guidelines for consumers and designers of multimedia learning. John Wiley \& Sons.

Creswell, J. W., \& Clark, V. P. (2011). Designing and conducting mixed research methods. Thousand Oaks, CA: Sage

Creswell, J. W. (2012). Educational Research: Planning, Conducting, and Evaluating Quantitative and Qualitative Research. 4th ed. USA: Pearson Education, Inc.

Darmawan, M. S., Daeni, F., \& Listiaji, P. (2020). The Use of Quizizz As An Online Assessment Application for Science Learning in The Pandemic Era. Unnes Science Education Journal, 9(3), 144-150.

Davis, F. D., Bagozzi, R. P., \& Warshaw, P. R. (1989). User acceptance of computer technology: a comparison of two theoretical models. Management science, 35(8), 982-1003.

DeVellis, R. F. (2016). Scale development: Theory and applications (Vol. 26). Sage publications.

De Vynck, G., \& Bergen, M. (2020). Google classroom users doubled as quarantines spread. Boomberg. Retrieved January, 11, 2021. https://www.bloomberg.com/news/articles/2020-0409/google-widens-lead-in-education-market-as-students-rush-online

Douell, M. (2020). Integrating Google Forms as a Means of Formative Assessment in the Elementary Math Classroom. https://egrove.olemiss.edu/hon_thesis/1467/

Ebrahimi, S. S., \& Jiar, Y. K. (2018). The Use of Technology at Malaysian Public High Schools. Merit Research Journal of Education and Review, 6(3), 54-60.

Englund, C., Olofsson, A. D., \& Price, L. (2017). Teaching with technology in higher education: understanding conceptual change and development in practice. Higher Education Research \& Development, 36(1), 73-87.

Fishbein, M., \& Ajzen, I. (1976). Misconceptions about the Fishbein model: Reflections on a study by Songer-Nocks. Journal of Experimental Social Psychology, 12(6), 579-584.

Gitau, M. W. (2016). Application of the utaut model to understand the factors influencing the use of web 2.0 tools in e-learning in Kenyan public universities (Doctoral dissertation, University of Nairobi).

Godwin-Jones, R. (2009). Personal learning environments. Language Learning \& Technology, 13(2), 3-9.

Gon, S., \& Rawekar, A. (2017). Effectivity of e-learning through WhatsApp as a teaching learning tool. MVP Journal of Medical Science, 4(1), 19-25.

Hair, J. F., Anderson, R. E., Tatham, R. L., \& Black, W. C. (1998). Multivariate data analysis (5th ed.). Englewood Cliffs, NJ: Prentice Hall.

Hennessy, S., Ruthven, K., \& Brindley, S. U. E. (2005). Teacher perspectives on integrating ICT into subject teaching: commitment, constraints, caution, and change. Journal of curriculum studies, $37(2), 155-192$.

Huang, F., Teo, T., \& Zhou, M. (2017). Understanding factors influencing English teachers in Chinese Universities to teach with technology: A case study. In New Ecology for EducationCommunication X Learning (pp. 119-130). Springer, Singapore.

Iivari, N., Sharma, S., \& Ventä-Olkkonen, L. (2020). Digital transformation of everyday life-How COVID-19 pandemic transformed the basic education of the young generation and why information management research should care? International Journal of Information Management, 55, 102183.

Junior, J. B. B. (2020). Assessment for learning with mobile apps: exploring the potential of quizizz in the educational context. International Journal of Development Research, 10(01), 33366-33371.

Kurniawati, D., \& Lestari, S. (2020). Using Google Forms for Online Listening Test: Does It Work?. English Education: Jurnal Tadris Bahasa Inggris, 13(2), 136-155.

Lin, P. C., Lu, H. K., \& Liu, S. C. (2013). Towards an education behavioral intention model for elearning systems: An extension of UTAUT. Journal of Theoretical \& Applied Information Technology, 47(3).

Mahande, R. D., \& Malago, J. D. (2019). An E-Learning Acceptance Evaluation through UTAUT Model in a Postgraduate Program. Journal of educators online, 16(2), n2.

Marqués-Sulé, E., Antón, C. M., Serrano, N. C., Iranzo, M. C. I., \& Sempere-Rubio, N. (2017). Using google forms as an on-line evaluation system in cardiovascular physiotherapy. In Edulearn17 Proceedings (pp. 1235-1240). IATED. 
McCulloch, A. W., Hollebrands, K., Lee, H., Harrison, T., \& Mutlu, A. (2018). Factors that influence secondary mathematics teachers' integration of technology in mathematics lessons. Computers \& Education, 123, 26-40.

McGorry, S. Y. (2002). Online, but on target? Internet-based MBA courses: A case study. The Internet and Higher Education, 5(2), 167-175.

Mei, B., Brown, G. T., \& Teo, T. (2018). Toward an understanding of preservice English as a Foreign Language teachers' acceptance of computer-assisted language learning 2.0 in the People's Republic of China. Journal of Educational Computing Research, 56(1), 74-104.

Moghavvemi, S., Sulaiman, A., Jaafar, N. I., \& Kasem, N. (2018). Social media as a complementary learning tool for teaching and learning: The case of YouTube. The International Journal of Management Education, 16(1), 37-42.

Mokhtar, H. S. (2020). Teachers explore online teaching methods during MCO. New Straits Times. https://www.nst.com.my/education/2020/03/579992/teachers-explore-online-teaching-methodsduring-mco [1 June 2020]

Moran, M. J. (2006). College student's acceptance of tablet personal computers: A modification of the Unified Theory of Acceptance and Use of Technology model (Doctoral dissertation, Capella University).

Mtebe, J. S., Mbwilo, B., \& Kissaka, M. M. (2016). Factors influencing teachers' use of multimedia enhanced content in secondary schools in Tanzania. International Review of Research in Open and Distributed Learning, 17(2), 65-84.

Nikou, S. A., \& Economides, A. A. (2019). Factors that influence behavioral intention to use mobilebased assessment: A STEM teachers' perspective. British Journal of Educational Technology, 50(2), 587-600.

Oliveira, A., Feyzi Behnagh, R., Ni, L., Mohsinah, A. A., Burgess, K. J., \& Guo, L. (2019). Emerging technologies as pedagogical tools for teaching and learning science: A literature review. Human Behavior and Emerging Technologies, 1(2), 149-160.

Patton, M. Q. (2002). Two decades of developments in qualitative inquiry: A personal, experiential perspective. Qualitative social work, 1(3), 261-283.

Prasojo, L., Habibi, A., Mukminin, A., Sofyan, S., Indrayana, B., \& Anwar, K. (2020). Factors Influencing Intention to Use Web 2.0 in Indonesian Vocational High Schools. International Journal of Emerging Technologies in Learning (iJET), 15(5), 100-118.

Pynoo, B., Devolder, P., Tondeur, J., Van Braak, J., Duyck, W., \& Duyck, P. (2011). Predicting secondary school teachers' acceptance and use of a digital learning environment: A crosssectional study. Computers in Human behavior, 27(1), 568-575.

Rahayu, I. S. D., \& Purnawarman, P. (2019, June). The Use of Quizizz in Improving Students' Grammar Understanding through Self-Assessment. In Eleventh Conference on Applied Linguistics (CONAPLIN 2018). Atlantis Press.

Raman, A., \& Rathakrishnan, M. (2018). FROG VLE: Teachers' technology acceptance using UTAUT model. International Journal of Mechanical Engineering and Technology, 9(3), 529538.

Sadaf, A., Newby, T. J., \& Ertmer, P. A. (2016). An investigation of the factors that influence preservice teachers' intentions and integration of Web 2.0 tools. Educational Technology Research and Development, 64(1), 37-64.

Sangeeta \& Tandon, U. (2020). Factors influencing adoption of online teaching by school teachers: A study during COVID-19 pandemic. Journal of Public Affairs, e2503.

Schulz, R., Isabwe, G. M., \& Reichert, F. (2015, September). Investigating teachers motivation to use ICT tools in higher education. In 2015 Internet Technologies and Applications (ITA) (pp. 6267). IEEE.

Shanmugam, S. K. S., \& Lee, S. M. (2017). Barriers of Implementing Action Research among Malaysian Teachers. Pertanika Journal of Social Sciences \& Humanities, 25(4).

Son, J. B. (2011). Online tools for language teaching. TESL-EJ, 15(1), 1-12.

Soon \& Wong. (2020). Dedicated teachers and tech help students continue studies online during MCO. The Star. https://www.thestar.com.my/lifestyle/family/2020/04/03/despite-the-stayhome-order-these-students-have-continued-with-their-lessons-online [1 June 2020]

Tan, P. J. B. (2013). Applying the UTAUT to understand factors affecting the use of English elearning websites in Taiwan. Sage Open, 3(4), 2158244013503837. 
Telenor Group. (2016). Youth hooked on mobile messaging but preference varies, says Telenor research: Telenor releases Digital Frontrunners study. https://www.telenor.com/media/pressrelease/youth-hooked-on-mobile-messaging-but-preference-varies-says-telenor-research [1 June 2020]

Teo, T., Sang, G., Mei, B., \& Hoi, C. K. W. (2019). Investigating pre-service teachers' acceptance of Web 2.0 technologies in their future teaching: a Chinese perspective. Interactive Learning Environments, 27(4), 530-546.

Thang, S. M., Lee, K. W., Murugaiah, P., Jaafar, N. M., Tan, C. K., \& Bukhari, N. I. A. (2016). ICT tools patterns of use among Malaysian ESL undergraduates. GEMA Online ${ }^{\circledR}$ Journal of Language Studies, 16(1).

Tiba, C., Condy, J., \& Tunjera, N. (2016). Re-examining factors influencing teachers' adoption and use of technology as a pedagogical tool. Empowering the 21 st Century Learner.

Trochim, W. M. (2006). The Research Methods Knowledge Base. (2nd Eds.). Cincinnati: Atomic Dog Publishing.

Tseng, T. H., Lin, S., Wang, Y. S., \& Liu, H. X. (2019). Investigating teachers' adoption of MOOCs: the perspective of UTAUT2. Interactive Learning Environments, 1-16.

UNESCO. (2020). COVID-19 Educational Disruption and Response. https://en.unesco.org/covid19/educationresponse [1 June 2020]

Venkatesh, V., Morris, M. G., Davis, G. B., \& Davis, F. D. (2003). User acceptance of information technology: Toward a unified view. MIS quarterly, 425-478.

Verma, A., Verma, S., Garg, P., \& Godara, R. (2020). Online teaching during COVID-19: perception of medical undergraduate students. Indian Journal of Surgery, 82(3), 299-300.

Walker R., Davies G. \& Hewer S. (2012). Introduction to the Internet. Module 1.5 in Davies G. (ed.) Information and Communications Technology for Language Teachers (ICT4LT), Slough, Thames Valley University [Online]. Available at: http://www.ict4lt.org/en/en_mod1-5.htm [30 May 2020].

Wang, Y. S., \& Shih, Y. W. (2009). Why do people use information kiosks? A validation of the Unified Theory of Acceptance and Use of Technology. Government information quarterly, 26(1), 158-165.

Wong, G. K. (2016). The behavioral intentions of Hong Kong primary teachers in adopting educational technology. Educational Technology Research and Development, 64(2), 313-338.

Yew, K. K. W., \& Tan, K. H. (2020). ESL Teachers' Intention in Adopting Online Educational Technologies during COVID-19 Pandemic. Journal of Education and E-Learning Research, 7(4), 387-394. https://doi.org/10.20448/journal.509.2020.74.387.394

Zakaria, M. H., Watson, J., \& Edwards, S. L. (2010). Investigating the use of Web 2.0 technology by Malaysian students. Multicultural Education \& Technology Journal.

Zuhriyah, S., \& Pratolo, B. W. (2020). Exploring Students' Views in the Use of Quizizz as an Assessment Tool in English as a Foreign Language (EFL) Class. Universal Journal of Educational Research, 8(11), 5312-5317. 